\title{
Effect of Cross-Border Acquisitions on Businesses Performance of Slovak Acquiring Companies*
}

\author{
Jana Kubicová, Miroslava Záhumenská \\ University of Economics in Bratislava, Bratislava, Slovak Republic
}

\begin{abstract}
Currently, businesses or companies apply various tools of financial engineering on improvement of their performance. One of such tools refers to acquisitions through which companies can profit from synergic effects, reduce operating cost and tax expenses, and improve their market position. This paper is aimed at examining the effect of cross-border acquisitions made by Slovak companies in order to improve their performance. Authors applied the method of simultaneous equation model to examine this relation. The result confirmed the hypothesis that cross-border acquisitions positively influence a company performance.
\end{abstract}

Keywords: acquisition, performance, Slovak company, mergers and acquisitions (M\&As) effect

\section{Introduction}

Currently, businesses or companies apply various tools of financial engineering on improvement of their performance. One of such tools refers to acquisitions through which companies can profit from synergic effects, reduce operating cost and tax expenses, and improve their market position. Figure 1 contains overview of countries in which a Slovak company acquired another company. It was prepared on basis of the data available to Slovak companies from the database (DB) Zephyr. Of total recorded 90 cross-border acquisitions, there were 36 Czech-Slovak acquisitions made by Slovak companies.

The primary focus of the research was at examining the effect of cross-border acquisitions made by Slovak companies in order to improve their performance. To achieve the objective of the research, authors compiled necessary data and then undertook an empirical analysis where they applied the method of simultaneous equation model. The rest of this paper is structured as follows: It begins by reviewing the relevant literature focusing on mergers and acquisitions (M\&As) effect on company profitability; it is followed by the section III where it develops hypothesis, specifies the model and data, and then describes used procedure and methodology; then section IV covers obtained empirical results; it is followed by section V which displays conclusions; and finally section VI shows references.

\footnotetext{
* Project Support: The paper has been prepared within framework of VEGA scientific research project No. 1/0238/13 titled

"Taxes and Effectiveness of Financial Re-engineering Tools to Improve the Performance of Companies in the Time of the Crisis".

Jana Kubicová, associate professor at the Department of Finance, University of Economics in Bratislava, Bratislava, Slovak Republic.

Miroslava Záhumenská, Ph.D. student at the Department of Finance, University of Economics in Bratislava, Bratislava, Slovak Republic.

Correspondence concerning this article should be addressed to Jana Kubicová, University of Economics in Bratislava, Dolnozemská cesta 1, 85235 Bratislava, Slovak Republic.
} 


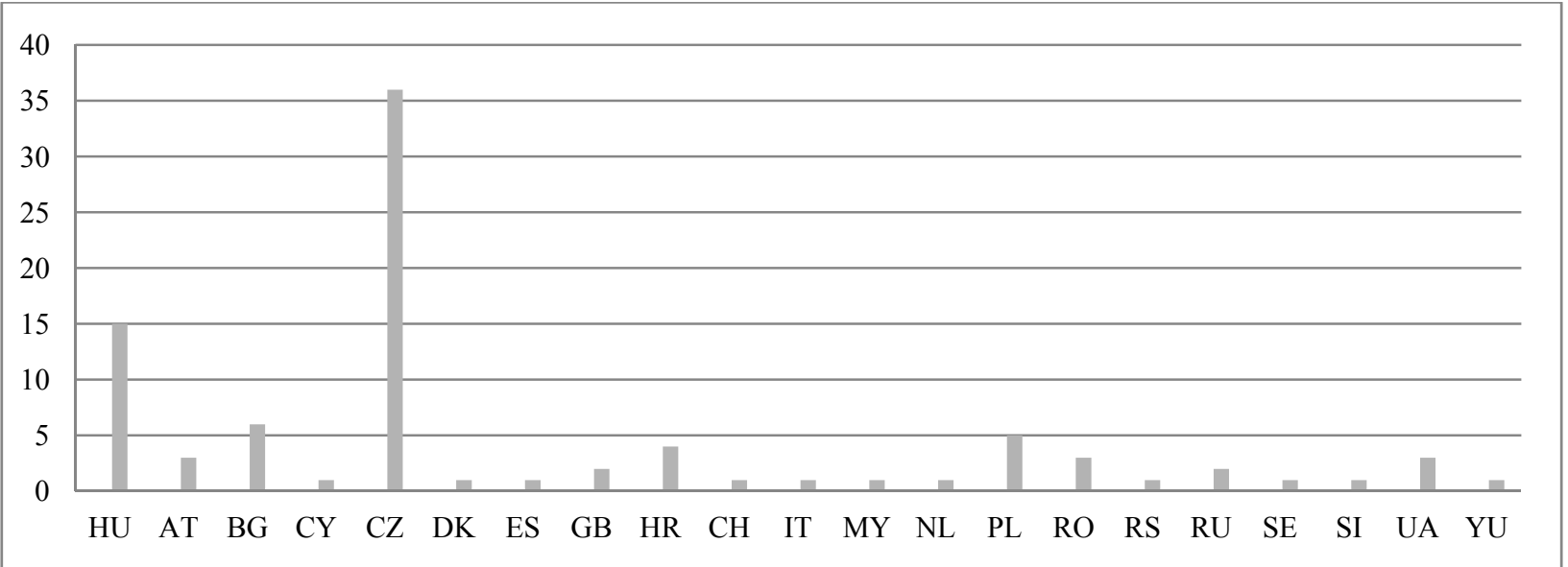

Figure 1. Number of cross-border acquisitions with Slovak company as an acquirer. Source: Own presentation of Zephyr.

\section{Literature Review}

There are many studies dealing with M\&As effect on company profitability. The studies dealing with the topic within period of year from 1971 to 2001 were prepared, for example by Bruner (2002) who summarized particular conclusions of various approaches to profitability measurement. Based on the analysis, he found out that it is worth implementing M\&As upon meeting certain preconditions. He also warned that a buyer's expectations might not always come true, since the synergy and effectiveness advantage is hard to reach.

Bertrand and Betschinger (2012) analyzed the effect of domestic and cross-border acquisitions on the Russian businesses performance in their thesis. Applying generalized method of moments (GMM) model estimation, they examined whether acquisition increased performance of the acquiring Russian company, where the assets cost - effectiveness was chosen a performance indicator. The survey was conducted on the sample of 600 companies and resulted in the observation that both domestic and cross-border acquisitions tend to reduce performance of acquiring company in Russia on par with a company not acquiring any company.

Akben-Selcuk and Altiok-Yilmaz (2011) focused on the analysis of M\&As effect on Turkish acquiring companies in their thesis, with the sample of 62 companies. They conducted the analysis from two points of view-the so-called stock market approach and accounting approach; examining whether M\&A application influences a company performance. The study resulted in different outcomes of both approaches.

Stiebale and Trax (2011) also dealt with the analysis of cross-border M\&As effect on performance of acquiring companies from Great Britain and France. Using combination of matching techniques with a difference-in-differences estimator, they analyzed the effect of even a single acquisition on selected company variables. The survey confirmed that cross-border acquisitions increase domestic employment rate along with other effects (number of employees as a company size parameter) and sales. The authors stated that cross-border M\&As are conditioned also with particular transaction motives.

Boateng, Qian, and Tianie (2008) dealt with the analysis of strategic motives and performance in case of cross-border M\&As. The analysis was performed on the sample of 27 cross-border M\&As performed by Chinese companies during period of years from 2000 to 2004. They found out that Chinese companies are influenced by a couple of motives to conduct cross-border M\&As (obtained strategic advantage, international expansion, and diversification). Thus, the authors supposed that cross-border M\&As conducted by Chinese companies result in positive and major benefits to acquiring companies' owners. 
Liu and Wang (2013) dedicated their work to examination of M\&As effect on company performance. The analysis was conducted via ordinary least squares (OLS) model on the sample of 36 M\&As made by Chinese real estate companies during period of years from 2008 to 2009. Their research resulted in observed positive effect of ownership structure on M\&As performance.

\section{Hypothesis, Model, and Methodology}

Acquisitions represent financial engineering tools through which the companies are able to obtain benefits in the form of synergic effects, reduction of operating cost and tax expenses, and improvement of their market position. Accordingly, this paper can state that cross-border acquisitions made by Slovak companies have potential to improve their performance. This article deals with examination of the effect of cross-border acquisitions made by Slovak companies on the improvement of their performance.

Because of different outcomes of the previous studies, determining the hypothesis, authors referred to the general approach to positive acquisition effect on the company performance. For purpose of the survey, they set forth the hypothesis on improved performance of a Slovak company, being an acquiring company, which makes a cross-border acquisition. The examination asks whether the cross-border acquisition represents a statistically significant parameter, i.e., whether or not it influences a company performance. If it proves to be a statistically significant parameter, examination will focus on the cross-border acquisition effect result and they expect it being positive.

They chose application of simultaneous equations for verification of the hypothesis. The method seems most suitable for examination of mutual relations at the company, since particular performance indicators are mutually interconnected.

They identified Slovak companies that conducted cross-border acquisition and acquired a company in abroad via database Zephyr. They found total 90 such acquisitions and that there were some cases of multiple acquisitions by a single Slovak company. Subsequently, using database Amadeus and the Public Register of Financial Reports, they obtained financial data about these companies. Since not all data were available regarding the companies, they did not include all companies in the model. Processing the data, they got total 24 companies with all required data available. At all parameters, they considered the period of three years preceding the acquisition and three years after the acquisition. The year of acquisition was excluded, since usually not standard acquisitions were made in this year.

They included also companies among those acquiring that did not make any cross-border acquisition. They chose 24 companies of comparable size to those with acquisitions. Companies of various sizes were chosen in the same ratio as included in observations related to companies making cross-border acquisitions. They drew financial data from the period of years from 2006 to 2012, since majority of acquisitions in the previous group of companies were conducted during these years.

They worked with cross-sectional data and the analysis was made through the following three-level model of simultaneous equations:

$$
\begin{aligned}
& \text { ROA_po }=\alpha_{0}+\alpha_{1} \text { ROA_pred }+\alpha_{2} \text { SALES_pred }+\alpha_{3} \log \mathrm{A} \_ \text {pred }+\alpha_{4} \log \mathrm{A} \_ \text {po }+\alpha_{5} \mathrm{AKVIZ} \\
& \text { ROE _po }=\beta_{0}+\beta_{1} \text { ROE } \_ \text {pred }+\beta_{2} \text { ROA_pred }+\beta_{3} \text { Sales_po }+\beta_{4} \text { EÚS_pred }+\beta_{5} \text { EÚS } \_ \text {po } \\
& \text { SALES_po }=\gamma_{0}+\gamma_{1} \text { ROE_po }+\gamma_{2} \text { ROA_pred }+\gamma_{3} \log \text { A_pred }+\gamma_{4} \text { ROA_po }+\gamma_{5} \text { SALES }_{t-1}+\gamma_{6} \text { EDS }
\end{aligned}
$$

Company should be understood as a certain system whose parts influence one another and are mutually interconnected. Application of simultaneous equations allows for examination of their effects and identification 
of influence, if any, of cross-border acquisition on the company performance improvement. They chose assets cost-effectiveness (ROA) (Bertrand \& Betschinger, 2012), own capital cost-effectiveness (ROE), and sales as the company performance indicators.

In the first equation, they presumed that the company making acquisition will be allowed to access new markets, increase production capacity, or install an additional production line. The change will be reflected in increased sales and further in increased operating profit expressed on ROA indicator. They presumed the existence of positive relation between post-acquisition return on assets and the acquisition transaction. Furthermore, they expected improvement of performance as a result of cross-border acquisition, reflected in positive relation between pre-acquisition return on assets (ROA_pred) and post-acquisition return on assets (ROA_po). Indicators - pre-acquisition assets logarithm (logA_pred) and post-acquisition assets logarithm ( $\log$ A_po), and pre-acquisition sales (Sales_pred) are perceived as indicators of the company size, presuming positive relation between these indicators and post-ROA. Big companies can better profit from the size-related savings and they are less risky, since they have usually diversified activities.

The second equation contains post-acquisition return on equity (ROE_po) as a company performance indicator. If the value is increased for the shareholders, it will be expressed in increased ROE, since it is an indicator of cost-effectiveness of own sources deposited in the company by its owner. Therefore, the authors presumed the existence of positive relation between post-ROE and ROE_po. As another indicator, the authors chose effective interest rate (EÚS), where lower EÚS means that the company cost of debts has dropped and it allows for better utilization of foreign capital and thus considered less risky. Therefore, they expected the negative value here (minus sign). In this case, they also expected dependence of the company size on its performance, since bigger companies benefit better from the size savings - this precondition is similar to the first equation. This paper included post-acquisition sales variable in the model (Sales_po) with expected positive value (plus sign).

This paper chose post-acquisition sales as an indicator in the third equation. It is presumed that the acquisition will increase the company sales as well as positive relation between pre-acquisition sales value (as well as pre- and post-indicator $\log \mathrm{A}$ ) and post-acquisition sales value. It included effective tax rate in the model in order to examine its effect on the performance (Table 1).

Table 1

Variables

\begin{tabular}{llll}
\hline Abbrev. & Variable & Description & Expected sign \\
\hline ROA & Return on assets & EBIT divided by total assets & + \\
ROE & Return on equity & EAT divided by equity & + \\
SALES & Sales & Sales in EUR & + \\
logA & Assets & Natural logarithm of assets from final accounts & + \\
AKVIZ & Acquisition made & Dummy variable-1 acquisition made, 0 acquisition not made & + \\
EÚS & Effective interest rate & Cost interest divided by interest bearing liabilities (bank loans) & - \\
EDS & Effective tax rate & Due tax divided by pre-tax profit/loss & \\
\hline
\end{tabular}

Source: Own document.

\section{Results}

Table 2 contains the results of three-stage least squares (3SLS) simultaneous equation model. The results confirmed the expectations that cross-border acquisitions influence increase of Slovak companies' performance. 
Results of the first equation indicate that the acquisition indicator represents a statistically significant variable, thus if a cross-border M\&A acquisition is made, the company performance increases by 0.15 unit. Similar positive effect was identified between independent variable - assets pre- and post-ROA. Pre-acquisition return on assets during particular period represents a statistically significant factor, i.e., the higher the value, the higher is the company performance increase. Also the company size indicator represents a statistically significant factor-post-acquisition assets value, i.e., if the company size increased, its performance will increase as well.

In case of return on equity performance indicator in the second equation, post-acquisition sales represent a significant impact, since the company has got new customers thanks to the acquisition and reached higher sales. Subsequently, based on the results reached, it can be stated that if the sales increase by Eur 1, ROE and company performance will increase as well.

The third equation resulted in the confirmation that pre-acquisition sales represent a statistically significant factor that is positively correlated with another performance indicator-post-acquisition sales. Accordingly, pre-M\&A sales represent a significant factor that influences performance, i.e., if pre-acquisition sales increased, post-acquisition sales would increase as well and also the company performance.

From the results reached, it can be seen that cross-border M\&As increased performance of Slovak companies being acquirers of other companies.

Table 2

Results of Three-Stage Least Squares (3SLS)

\begin{tabular}{|c|c|c|c|}
\hline & Equation 1 & Equation 2 & Equation 3 \\
\hline const & $\begin{array}{l}-0.301033 \\
(0.1846)\end{array}$ & $\begin{array}{l}-0.482495 \\
(0.0504)^{*}\end{array}$ & $\begin{array}{l}-1.27716 e+08 \\
(0.0974)^{*}\end{array}$ \\
\hline ROA_pred & $\begin{array}{l}0.691489 \\
(1.11 e-06)^{* * *}\end{array}$ & & \\
\hline Sales_pred & $\begin{array}{l}1.77647 e-010 \\
(0.7362)\end{array}$ & & $\begin{array}{l}0.150027 \\
(0.0082)^{* * *}\end{array}$ \\
\hline 1_aktiva_pred & $\begin{array}{l}-0.0528042 \\
(0.1170)\end{array}$ & & $\begin{array}{l}8.39444 e+06 \\
(0.1556)\end{array}$ \\
\hline 1_aktiva_po & $\begin{array}{l}0.0675201 \\
(0.0354)^{* *}\end{array}$ & & $\begin{array}{l}1.55216 e+06 \\
(0.7769)\end{array}$ \\
\hline akviz & $\begin{array}{l}0.156354 \\
(0.0936)^{*}\end{array}$ & & \\
\hline ROE_pred & & $\begin{array}{l}-0.198373 \\
(0.4058)\end{array}$ & \\
\hline ROE_po & & & $\begin{array}{l}8.61759 e+06 \\
(0.7848)\end{array}$ \\
\hline EÚS_pred & & $\begin{array}{l}0.000496264 \\
(0.9385)\end{array}$ & \\
\hline EÚS_po & & $\begin{array}{l}-0.00509183 \\
(0.7289)\end{array}$ & \\
\hline EDS & & & $\begin{array}{l}1.53614 e+06 \\
(0.5138)\end{array}$ \\
\hline Sales_po & & $\begin{array}{l}9.24554 \mathrm{e}-09 \\
(0.0299)^{* *}\end{array}$ & \\
\hline ROA_po & & & $\begin{array}{l}4.32194 e+07 \\
(0.3496)\end{array}$ \\
\hline$R$ squared & 0.394176 & 0.012475 & 0.256757 \\
\hline
\end{tabular}

Notes. *** Statistical level of significance $P \leq 0.001$; ** statistical level of significance $P \leq 0.01$; and $*$ statistical level of significance $P \leq 0.05$. Source: Own calculations via SW Gretl. 
Despite of the results reached, it should be stated that the model of simultaneous equations contains low values of indicator $R^{2}$, i.e., there are other variables that affect dependant variables chosen by the authors.

\section{Conclusions}

This paper has been aimed at analyzing whether or not the cross-border acquisitions influence Slovak companies performance improvement. It set forth the hypothesis that cross-border acquisition positively influences performance of a company acquiring another company. To confirm this hypothesis, the authors applied the model of simultaneous equations. The results indicate that Slovak companies that made a cross-border acquisition reported improved performance on par with companies without a cross-border acquisition made.

Outcomes of this paper can significantly influence decision-making of a company regarding a future cross-border acquisition. Companies often hesitate whether or not to conduct such transaction, since it is much more complicated that a domestic transaction, because of a cross-border factor, is representing certain risk and uncertainty. However, the analysis confirmed that a cross-border acquisition has a positive impact on the company. Thus, it suggests companies to make as many cross-border acquisitions as possible, since it has potential of a positive impact on the company.

While the analysis outcomes confirmed the hypothesis, indicator $R^{2}$ pointed out to other factors that could significantly contribute to a company performance improvement. Therefore, further research should focus on investigation of such variables.

\section{References}

Akben-Selcuk, A., \& Altiok-Yilmaz, A. (2011). The impact of mergers and acquisitions on acquirer performance: Evidence from Turkey. Retrieved from $\mathrm{http}$ //www.omicsonline.com/open-access/the-impact-of-mergers-and-acquisitions-on-acquirer-performance-evidence-from- $\mathrm{t}$ urkey-2151-6219-2-022.pdf?aid=13948

Bertrand, O., \& Betschinger, M. A. (2012). Peformance of domestic and cross-border acquisitions: Empirical evidence from Russian acquirers. Journal of Comparative Economics, 40(3), 413-437.

Boateng, A., Qian, W., \& Tianie, Y. (2008). Cross-border M\&As by Chinese firms: An analysis of strategic motives and performance. Thunderbird International Management Review, 50(4), 259-270.

Bruner, R. F. (2002). Does M\&As pay? A survey of evidence for the decision-maker. Journal of Applied Finance, 12(1), 48-68.

Liu, Y., \& Wang, Y. (2013). Performance of mergers and acquisitions under corporate governance perspective. Open Journal of Social Sciences, 1(6), 17-25.

Stiebale, J., \& Trax, M. (2011). The effects of cross-border M\&As on the acquirers' domestic performance: Firm-level evidence. Canadian Journal of Economics, 44(3), 957-990. 